\title{
Microstructure and Microanalysis of Crept Alloy 740
}

\author{
N.D. Evans*, P.J. Maziasz*, R.W. Swindeman*, and G.D. Smith** \\ * Metals \& Ceramics Div., Oak Ridge National Laboratory, Oak Ridge, TN 37831, USA \\ ** Special Metals Corporation, Huntington, WV 25705, USA
}

Alloy 740 is a new Ni-Cr-Co superalloy developed by Special Metals Corp. for ultra-supercritical steam boiler tubing applications [1]. To evaluate the potential for using alloy 740 above $700^{\circ} \mathrm{C}$, this work examines the stability or aging effects on the initial precipitation-hardened microstructure after creep-rupture testing at $816^{\circ} \mathrm{C}$. Here, material was solution annealed $0.5 \mathrm{~h}$ at $1200^{\circ} \mathrm{C}$, followed by $16 \mathrm{~h}$ at $800^{\circ} \mathrm{C}$, then crept $2500 \mathrm{~h}$ at $816^{\circ} \mathrm{C} / 20 \mathrm{ksi}$. Both uncrept and crept samples were examined by scanning electron microscopy (SEM) and transmission electron microscopy (TEM).

The uncrept alloy consists of a matrix of disordered fcc $\gamma$ with typically 50-nm-diam. ordered fcc $\gamma^{\prime}$ precipitates. Grain boundaries appear free of precipitates (Fig. 1a). In contrast, the backscattered electron (BSE) image acquired from the crept specimen reveals that grain boundaries are heavily decorated with at least two phases, and a phase having a lath morphology extends from grain boundaries and twin boundaries into the matrix (Fig. 1b).

Phase identification via TEM was accomplished by combined EDS and selected area diffraction (SAD) analysis [2]. Measured compositions of identified phases (for elements with atomic number $\mathrm{Z}>12$ ) are listed in Table 1. Figure 2, from the crept specimen, shows the expected $\gamma$ phase and a $\gamma^{\prime}$ precipitate ([001] diffraction pattern in Fig. 3a), and the lath phase. Diffraction patterns from the lath can be indexed as hcp $\eta$ (eta) phase (Fig. 3b). Grain boundary phases (Fig. 4a, and 4b with an inset BSE image to verify phase is within a boundary) were identified as fcc chromium carbide, $\mathrm{M}_{23} \mathrm{C}_{6}$ (Fig. 3c) and fcc G phase (Fig. 3d), which is a complex silicide, respectively.

TABLE 1. Measured Composition (at.\%) of phases observed in crept Alloy 740 by EDS

\begin{tabular}{cccccccccc}
\hline Phase & Al & Si & Ti & $\mathbf{C r}$ & Fe & Co & Ni & Nb & Mo \\
\hline $\boldsymbol{\gamma}$ & 0.1 & 0.3 & 0.3 & 32.7 & 0.5 & 21.2 & 44.6 & 0.2 & 0.1 \\
$\boldsymbol{\gamma}^{\prime}$ & 6.1 & - & 10.0 & 1.6 & 0.3 & 6.2 & 73.3 & 2.4 & - \\
$\boldsymbol{\eta}$ & 2.3 & - & 10.4 & 1.3 & 0.1 & 8.9 & 71.0 & 6.0 & - \\
$\mathbf{M}_{\mathbf{2 3}} \mathbf{C}_{\mathbf{6}}$ & - & - & 0.1 & 93.4 & - & 1.6 & 3.4 & - & 1.2 \\
$\mathbf{G}$ & 0.1 & 21.9 & 2.8 & 2.1 & 0.1 & 10.1 & 47.3 & 15.3 & 0.2 \\
\hline
\end{tabular}

Preliminary analysis shows that creep at $816^{\circ} \mathrm{C}$ for $2500 \mathrm{~h}$ produces significant changes in the initial as-heat-treated microstructure of alloy 740. Within grains, initially coherent $\gamma^{\prime}$ loses coherency and coarsens during creep. Significant precipitation occurs along grain boundaries, including coarse laths of eta phase, and smaller particles of $\mathrm{M}_{23} \mathrm{C}_{6}$ and G-phase silicide.

[1] G.D. Smith and H.W. Sizek, paper number 256 presented at NACE 2000, NACE-International, Houston. [2] M.J. Donachie and S.J. Donachie, Superalloys: a Technical Guide, $2^{\text {nd }}$ Ed., ASM International, Metals Park, OH 2002.

[3] Research at the Oak Ridge National Laboratory SHaRE Collaborative Research Center was sponsored by the Office of Fossil Energy, Advanced Research Materials Program and the Division of Materials Sciences and Engineering, U.S. Department of Energy, under contract DE-AC05-00OR22725 with UT-Battelle, LLC. 
Discussions with E.A. Kenik, ORNL, and M.G. Burke, Bettis Laboratory, are gratefully acknowledged.

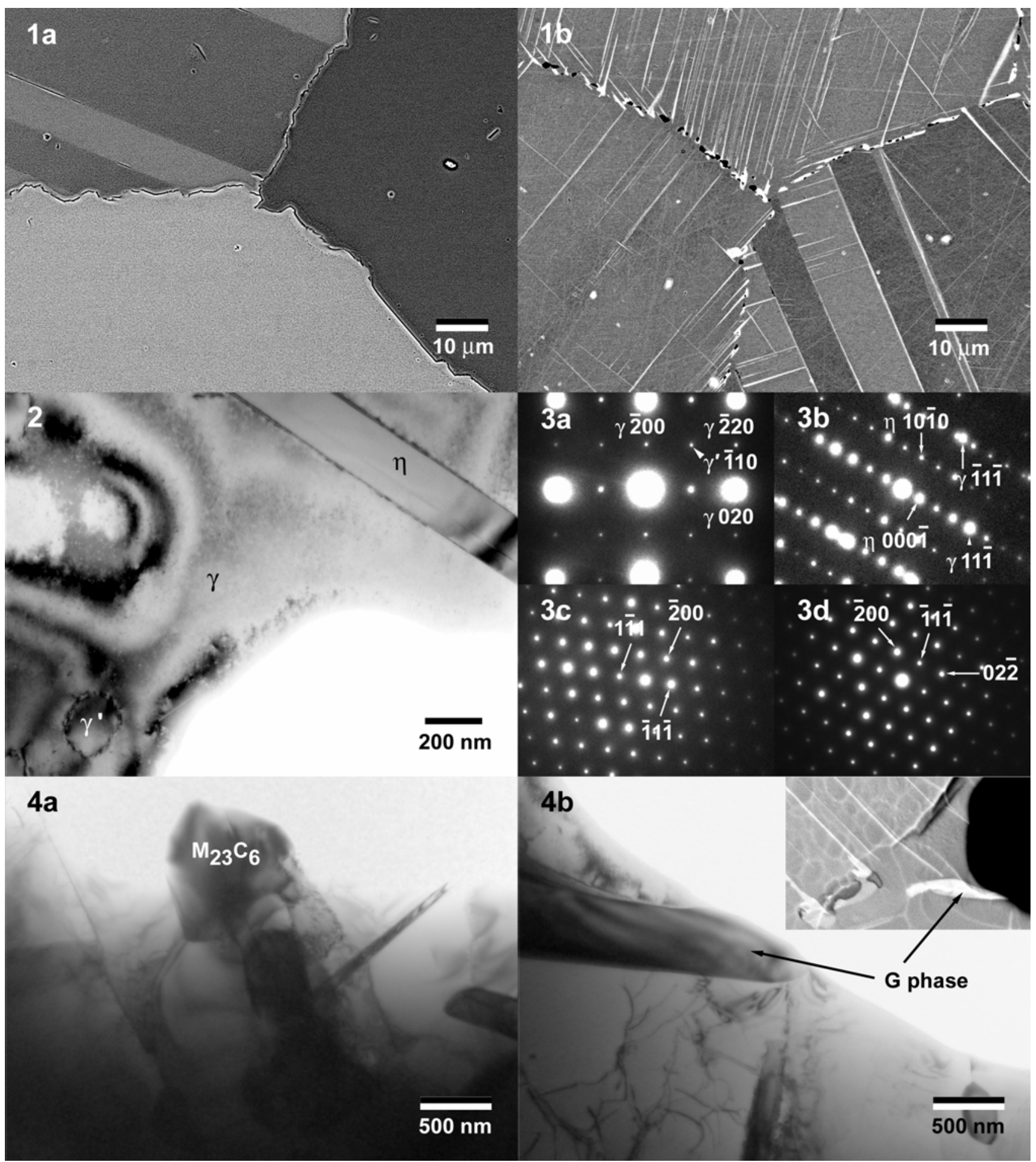

Fig. 1 SEM BSE images of a) uncrept Alloy 740; b) crept Alloy 740

Fig. 2 TEM image of crept Alloy 740 shows continuous $\gamma, \gamma^{\prime}$ precipitate, and $\eta$ lath

Fig. 3 SAD patterns from a) [001] $\gamma$ with $\gamma^{\prime}$; b) [12 10$]$ ๆ; c) [011] $\mathrm{M}_{23} \mathrm{C}_{6}$; d) [011] G phase

Fig. 4 Grain boundary phases in crept Alloy 740 a) $\mathrm{M}_{23} \mathrm{C}_{6}$; b) $\mathrm{G}$ phase 